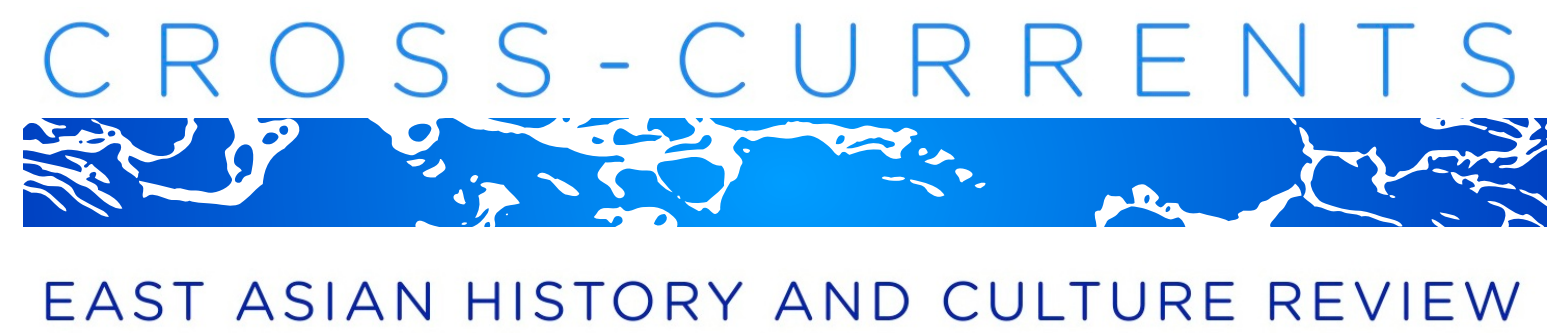

\title{
A Spectacle of Maps: Cartographic Hopes and Anxieties in the Pamirs
}

Martin Saxer, Ludwig Maximilian University of Munich

\begin{abstract}
Over the past 150 years, a great number of cartographic anxieties and hopes have shaped lives and relations in the Pamirs. The Great Game over imperial spheres of influence was followed by Soviet and Chinese anxieties regarding territorial integrity and the loyalty of their borderland populations; since the end of the Cold War, settling the remaining demarcated borders has become a primary concern in Central Asia; meanwhile, mining companies are anxious to claim territories for mineral extraction, and the maps of national parks and nature reserves aim at mitigating ecological anxieties and claim spaces for conservation. The result is a veritable spectacle of maps. Following Rob Kitchin and Martin Dodge (2007), this article argues that maps are "ontogenetic" rather than representational - they foster realities on the ground. Mapmaking projects derived from cartographic anxieties are embedded in particular visions of the future, and thus they can serve as a vantage point from which to explore the changing modes of outside engagement in the Pamirs.
\end{abstract}

Keywords: Pamirs, Tajikistan, history, Moscow provisioning, Tajik National Park, mining, map making, cartographic anxiety

The red line blazed upon the world map - the border of the Soviet soil sparkled like the verge of two epochs, like a border between the past and the future.

-Nikolai Nikolaevich Mikhailov, On the Map of the Motherland, 1947

\section{Introduction}

On November 2, 1907, Lord Curzon of Kedleston delivered a lecture at the Sheldonian Theater in Oxford. Looking back on his career as undersecretary of state and later as viceroy of India, he said, "I had had official cognizance of a period of great anxiety, when the main sources of diplomatic preoccupation, and sometimes of international danger, had been the determination of the Frontiers of the Empire in Central Asia" (Curzon 1907, A2). Frontiers, he noted, were the subject of four out of five international treaties, and yet, as a topic of scientific inquiry, frontiers were largely ignored. "Their incomparable drama," Curzon said, "are the possession of a few 
silent men, who may be found in the clubs of London, or Paris, or Berlin, when they are not engaged in tracing lines upon the unknown areas of the earth" (Curzon 1907, 5).

While borders have since become a much-debated issue in academia, the drawing of lines on maps is arguably still "the possession of a few silent men." The anxieties in which their endeavors are embedded continue to transform the territories to which their pens refer, although not always in the ways foreseen. Over the past 150 years, a great deal of cartographic anxiety has shaped the lives and relations of people in the Pamirs. The Great Game over spheres of influence was followed by Soviet and Chinese anxieties regarding territorial integrity and the loyalty of their borderland populations. After the end of the Cold War, settling the remaining undemarcated borders became a primary concern in Central Asia.

Furthermore, the notion of anxiety lends itself well to a range of inquiries that go beyond the question of state borders. Anxiety refers not only to fear but also to ambition. Followed by an infinitive, the term "anxious" alludes to potential futures of various kinds. Mining companies, for instance, are anxious to claim territories for mineral extraction, and the maps of national parks and nature reserves are directly tied to ecological anxiety and the need for conservation.

I use the term "cartographic anxiety" here in a simple and encompassing way to denote fears and hopes relating to and deriving from maps. The maps used and produced in the context of cartographic anxiety have one thing in common: rather than being mere representations of existing geographic realities, they hold particular visions of potential futures. Whether designed to justify, guide, or prohibit action, they are tied to these visions of potential futures. Thus, maps relate to time as much as to space. The process of their making is part and parcel of what social anthropologist Madeleine Reeves (Reeves 2014) calls "border work." Although often meant to mitigate cartographic anxiety, maps thereby also help produce it. While they may seem "a mere instrument of utility, showing us where to go and how to put things in place," as historian David Ludden notes, maps also contain "invisible ingredients" that "render every map a Pandora's box" (Ludden 2003, 1057). This article suggests that cartographic anxiety is typically a concern of outsiders. It tends to arise far away from the places it is concerned with; and, as with all anxieties, it is usually vague. Yet such anxieties inspire and condition powerful interventions and thus continue to drive far-reaching transformations on the ground.

This article explores the various cartographic anxieties that have been at work in the Pamirs over the past 150 years and asks how these anxieties gave rise to particular modes of 
engagement of outside powers with realities on the ground. However, my goal is not to develop the notion of cartographic anxiety into an all-embracing concept of imperial, colonial, and socialist agendas. Rather, I take the notion of cartographic anxiety for a walk through history and use it to think through a set of ideologically underpinned large-scale interventions. This conceptual approach comes at a price, as it necessarily glosses over much ethnographic and historical detail. What I hope it yields in exchange is the opening of a space in which these interventions can be understood in relation to one another.

The article follows a roughly chronological timeline, starting with the Great Game anxieties to which Curzon referred in his Oxford lecture. The neat red lines drawn on paper by faraway, silent men went along with considerable cartographic uncertainties and ambiguities on the ground. In the second section, I look at Soviet approaches to dealing with these inherited red lines and their associated ambiguities by way of actively trying to forge a loyal borderland population. To make sense of this particular mode of engagement, I introduce the notion of "curation" to denote a set of ambitions and practices that seek to link a particular ideology with an envisioned experience. Curational interventions, I argue, are never total; they are typically only partially successful and leave behind ruins on which subsequent interventions take place. The last section-"A Spectacle of Maps"-employs the notions of curation and anxiety to explore contemporary spatial concerns in the Pamirs: the transportation corridor linking Kashgar and Dushanbe, the Tajik National Park, and mining companies prospecting for minerals. I argue that over the past couple of decades the Pamirs have witnessed a multiplicity of map-making projects attached to particular cartographic hopes and fears. The result of this multiplication is a veritable spectacle of maps.

\section{Great Game Anxieties}

A term often used with regard to the nineteenth-century Anglo-Russian rivalry in Central Asia is "spheres of influence." It emerged as a diplomatic concept in 1869, when Count Gorchakov assured Lord Clarendon that "Afghanistan lay completely outside the sphere within which Russia might be called upon to exercise her influence" (Curzon 1907, 42). The notion of "spheres of influence" reflects both the vagueness and urgency of geopolitical anxieties during the Great Game. These anxieties were cartographic in two ways. First, spatial concerns for potential futures directly stemmed from studying existing maps that conjured up strategic 
opportunities and fears of strategic disadvantages. Second, these geopolitical anxieties were dealt with by making new maps - better maps that would allow for diplomatic and potentially military action to mitigate these anxieties.

The Pamirs became one of the focal points of Great Game cartographic fears and ambitions. After the Russian annexation of Tashkent in 1865 and Kokand in 1868, the British were anxious about the possibility of Russian influence extending toward Afghanistan, Xinjiang, and, finally, British India (cf. Lattimore 1950, 38-44). The British Crown came to the conclusion that "Afghanistan could no longer have nebulous boundaries" and pushed for a diplomatic accord that would stop Russian advances "south through Central Asia” (Rowe 2010, 59). The first Anglo-Russian agreement, reached in 1873, defined Badakhshan and the Wakhan as part of Afghanistan, and thus within the British sphere of influence (Geographer Office of the Geographer Bureau of Intelligence and Research 1983; Ewans 2010). The Russian occupation of Merv in 1884, however, made the British realize that the 1873 agreement was not set in stone. A more solid diplomatic solution needed to be found. A British-Russian boundary commission was set up, and two generals - Schveikovskyi for the Russians and Gerard for the British-were tasked with surveying the Pamir frontiers. In 1895, both sides signed an agreement stating that "territory lying within the British sphere of influence between the Hindu Kush and the line running from the east end of Lake Victoria (Zor Koul) to the Chinese frontier shall form part of the territory of the Ameer of Afghanistan, that it shall not be annexed to Great Britain and that no military posts or forts shall be established on it" (Habberton 1937, cited in Rowe 2010, 63). Neither Afghan nor Chinese representatives were involved in these negotiations.

However, in the early 1880s, Russia also started negotiating boundaries with China. After reconquering Kashgaria from Yaqub Beg, the Qing claimed that most of the Pamirs, including the Wakhan and Shugnan, had been part of Yaqub Beg's realm and thus belonged to the Chinese Empire. Chinese troops set up forts in Karakul, Yashilkul, Rangkul, and Aktash, and at least once encountered a Russian detachment (Garver 1981, 111). A joint border demarcation commission was set up in 1882. Two years later, on May 22, 1884, General Medinsky met with Chinese representatives in Novy Margilan to sign an agreement that defined the boundary from the Tianshan to the Pamirs. In the Pamirs, the borderline followed the Sarykol Range to the Uzbel Pass. Beyond Uzbel, however, the agreement stated only that the Chinese and Russian borders continued along lines south and southwest, respectively, creating a wedge of no-man's- 
land covering a considerable part of the present-day Tajik Pamirs (Kraudzun 2012, 176; Alimov 2014, 91-100). According to political scientist John Garver, this ambivalence was consistent with Russian objectives. He argues that "Russian strategy during this period was to prevent delimitation of boundaries which would block her [Russia's] advance further south" (Garver 1981, 112).

In 1893 the Russians established a garrison near Murghab known as Pamirskyi Post. By then, the Chinese troops had withdrawn from the Pamirs, and the Russian side insisted that the Sarykol Range should also be the boundary beyond the agreed-upon end point at Uzbel. New Sino-Russian negotiations began over the hitherto undefined boundary line south of Uzbel. Against the background of the growing tensions between China and Japan over Korea and the Chinese hope for Russian assistance in this matter, the Chinese agreed to the Russian position. In an exchange of notes, the Sarykol Range was defined as a provisional boundary to be settled in detail at a later stage (Garver 1981, 115).

The vast majority of Great Game literature, from Hopkirk (1990) to Sergeev (2013), deals with such agreements over spheres of influence and the cartographic anxieties these agreements were imbued with. This focus has two problems, however: first, it tends to foreground imperial strategic reasoning and give little regard to other, equally important dimensions of Central Asian history, such as the Jadid reformers, pan-Turkic movements, and the role of the Ottoman Empire. Largely missing are micro-historical analyses of concurrent transformations in the region that take into account the variety of forces and interests at work (see, for example, Bergne 2007; Bazarbayev and Adilbekova 2012; Morrison 2013, 2014; Abashin 2014; Weller 2014).

The second problem is that conceiving of the late nineteenth-century history of the region as the story of the Great Game inherently emphasizes rivalry and thereby gives prominence to the hawkish factions of British and Russian elites. Historian Ian Campbell argues that while the heroic tales of British and Russian explorers and military commanders are part and parcel of this narrative, "little attention has been paid to the culture of exploration - the methodologies and epistemological frames through which Russian and British observers apprehended and constructed their object of study" $(2014,200)$. This leads us to the other side of cartographic anxiety - not the nervous strategic rivalry but the shared ambition to map a region about which little is known. 
The unfolding geopolitical tensions over spheres of influence went hand in hand with considerable cartographic uncertainty. After Scottish explorer John Wood's 1838 expedition in search of the source of the Oxus River, geographical knowledge about the Pamirs was still sketchy and incoherent (Rawlinson 1872). The British trained a number of "native explorers" to gather better geographical information (Kreutzmann 2015, 72-82). The unmapped spaces promised fame and careers for those explorers with the courage to risk their lives—both in Saint Petersburg and in London. More scientific competitors than military rivals, these explorers shared a common ideological understanding of their mission, namely to fill one of the last remaining white spots on the map of the world. A number of geographical expeditions explored the Pamirs between the 1870s and the end of the century (Middleton 2011, 395-436; Kreutzmann 2015, 69-114).

In 1871, the Russian Alexei Fedchenko reached the Alai Valley and toured the northern Pamirs but was unable to proceed southward into present-day Tajikistan (Middleton 2011, 387395); as part of Thomas Douglas Forsyth's second Yarkand mission, Thomas Edward Gorden traveled through the Pamirs and the Wakhan in 1873-1874 (Gordon 1875); in 1877-1878, Nikolai Severtzov ventured south from the Alai and followed a route close to the current Pamir Highway, reaching Yashil Kul and the Ghunt Valley (Kreutzmann 2016); in 1884, on his first expedition, Grigory Grumm-Grzhimaylo traveled from the Alai as far as Lake Karakul (Grieshuber and Churkin 2003); and, in 1888-1889, Bronislav Gromchevsky crossed the Pamirs on his way to the Hunza Valley, where he encountered Francis Younghusband (Hopkirk 1990, 455-464). Two years later, in 1891, Younghusband toured the Pamirs and famously encountered Colonel Yonoff-well inside the territory that the 1873 agreement had set out as Afghan and thus, by implication, within the British sphere of influence (Younghusband 1896, 326-332). In 1890, several more explorers crossed the Pamirs, including the Earl of Dunmore and Sven Hedin (Hedin 1898).

The sporadic encounters between these expeditions were usually cordial, and the protagonists shared a common understanding of their task-quite in contrast to the hostile rhetoric of the hawkish Great Gamers in Saint Petersburg and London (Kreutzmann 2015, 9295).

The strategic, geopolitical concerns were rather out of proportion given the situation on the ground. According to a census by Captain Kuznetsov, there were only 1,055 Kyrgyz herders 
in the Eastern Pamirs, many of whom only spent the summer months on the pastures of Rangkul, Murghab, and Alichur. Their livestock included about 1,700 yaks, 20,000 sheep, 380 camels, and 280 horses. The population in the western Pamirs including the Wakhan was about 35,000. Only around 160 troops were stationed in Pamirskyi Post (Hedin 1898, 172, 176-177). The British officers, administrators, and imperial explorers with firsthand knowledge of the region were generally of the opinion that, given the topography, there was hardly any danger that a Russian army could use the Pamirs as a back door to India. Not a tad of geopolitical anxiety can be sensed in the reports of Younghusband or Hedin. However, the scientific cartographic ambition to map what was conceived of as terra incognita was entwined with larger geopolitical anxieties. Anxious to contribute to universal geographical knowledge, the Great Game explorers found that their careers and funding was tied to a discourse that rendered the Pamirs as a "pivot," "gap," or "back door" in the context of greater geopolitical schemes.

"More people debated than actually played the Great Game," historian and journalist John Keay once noted $(1977,145)$, and one may rightfully ask whether the Great Game was in fact a myth rather than a reality (Hopkins 2008, 34-60; Middleton 2011, 295-330). However, this question is not my primary concern. Important here is the fact that the adventurous sagas of the few brave men who traveled through the Pamirs captured the minds of large audiences in Europe and inserted local place names like Aktash and Bozai Gumbez into dinner conversations in European capitals - sometimes to the surprise of the adventurers themselves. Younghusband, for example, wrote about Bozai Gumbez, the site of his encounter with Yonoff in the Little Pamir, that "so much has since been written about this place, that people might easily imagine it to be a town or large village, whereas the only building on the spot is the tomb of a murdered Kirghiz chieftain, and the only inhabitants occasional nomadic Wakhis" (1896, 326).

Such descriptions reinforced the notion of a remote and empty expanse of mountainous territory with nothing but the occasional trace of a history long gone. The cartographic enterprise embedded in both the solemn travels of explorers and the geopolitical anxieties in imperial centers helped create the image of a desolate periphery at the edge of empires, devoid of its longstanding role as juncture between China and Central Asia. This idea of the remote, empty periphery with potential strategic importance, inscribed on the paper of maps and agreements during the Great Game, would have a profound and lasting effect-not only in the Pamirs but throughout the highlands of Asia, from the Pamirian Knot to the eastern slopes of the Himalayas. 
"After all, we do not desire to know a country in order to map it, but we map it in order to know it," British explorer Robert Shaw wrote in his travelogue (1871, 18). But mapping was more than this. The maps produced in the context of cartographic anxieties would slowly, over the course of a century, create realities on the ground. They were not just representations of geographical realities but tools and symbols in an abstract concern for space and universal geographical knowledge. They established a scientific, strategic, and diplomatic mode of engagement with a region emptied of its history and people. In other words, these maps were not graphical reflections of reality, and thus they did not enjoy "ontological security," as geographers Rob Kitchin and Martin Dodge put it (2007); instead, they were ontogenetic - they produced reality, and they created the territories they pretended to describe. The maps were "hyperreal" in Jean Baudrillard's sense-models generating a real without origin or reality. As such, the territory no longer precedes the map, nor does it survive it. Henceforth, it is the map that precedes and engenders the territory (Baudrillard 2002, 166). Michel de Certeau would say that such maps are "strategic" in the sense that they follow a "calculus of force-relationships" and assume "a place that can be circumscribed as proper (propre) and thus serve as the basis for generating relations with an exterior distinct from it" (1984, xix). The proper, de Certeau argues, is a victory of space.

Curzon would have agreed with the ontogenetic nature of maps that circumscribe a "proper place" and thus serve as a basis for relationships with an exterior. His 1907 lecture on frontiers ends on a note of hope. "Progress in the delimitation of frontiers is positive and real," he wrote. The general direction is forward. Scientific knowledge wins out against prejudice, "ethnological and topographical considerations are fairly weighed," and "the conscience of nations is more and more involved" (Curzon 1907, 53). Once borders were properly delimitated, they would end uncertainty and provide the basis for peaceful coexistence and orderly exchange. Curzon reasoned that boundaries, once fixed on maps, would indeed alleviate cartographic anxiety. This, we know in hindsight, is not what happened. Rather, the maps with their red boundary lines turned out to be, in Ludden's words, a kind of Pandora's box $(2003,1057)$.

\section{Curating the Borderland}

The Soviet Union inherited the imperial borders drawn during the Great Game. Fixed in treaties devoid of local participation and fuzzy in detail, they did little to curb the cartographic 
anxieties of the Bolshevik government. With the Republic of China succeeding the Qing Empire in 1912, a variety of stakes and political projects - many of them entangled with European interests - made the Asian frontiers of the young Soviet Union appear volatile and threatening. Surrounded by hostile imperialism, the Soviet concern was not one of spheres of influence but one of actual territorial integrity. A Westphalian logic of sovereign and territorially integral states superseded Great Game concerns. The fragile skin of the state's geo-body (Thongchai 1994) required a different form of attention and protection: a border na zamok - under lock and key (Shaw 2011).

Given the vastness of the frontier and the political turmoil along the Soviet Union's southern Asian borders, securing the border could not be accomplished with troops and military forts alone. Real state structures were to be established and the support of local borderland populations was to be gained. At stake was thus a double task, as social and cultural historian Charles Shaw notes: securing the border and replacing oppression with friendship and trust. "This was simultaneously a state-building and a nation-building process that involved linking patchwork islands of familiarity into one solid fabric where all could feel at home" (Shaw 2011, $331)$.

During the turbulent years following the October Revolution of 1917, Soviet power was still weak in Central Asia. The Basmachestvo Rebellion was in full swing, and establishing state structures was a formidable task (Fraser 1987; Olcott 1981; Ritter 1985). For the Bolshevik government and its People's Commissariat of Nationalities (Narkomnats, headed by Stalin), it was clear that the administrative structure inherited from the czarist empire was not a suitable basis for moving forward. The map of internal divisions of the Soviet Union had to be redrawn. This comprehensive cartographic project became known as natsional'no-territorial'noe razmezhevanie - the National-Territorial Delimitation of 1924 (Sabol 1995; Martin 2001; Haugen 2003; Bergne 2007, 39-54).

The ideology and rhetoric that underpinned this cartographic endeavor was one of liberation as well as national self-determination. The Soviet policy approach to national or ethnic identity (natsional'nost') played a crucial role in this respect. The Soviet state understood itself not as a new imperial power, but as a voluntary union of nation-states under the guidance of the Communist Party (Kreutzmann 2015, 367; Reeves 2014, 66-68). Ethnographers were sent out to gather scientific data on the languages, ways of life, and ethnic identities of the populations of 
Central Asia in order to define mono-ethnic (odnorodnye) territories (Hirsch 2005). This often turned out to be impossible given the multiethnic population in many places and the limited time for in-depth study. The practical cartographic decisions were thus often informed by a variety of concerns, including economic and political considerations (Bergne 2007, 43-45).

The Pamirs posed an especially tricky challenge in this regard. The internal administrative boundaries taken over from the Russian Empire split the Pamirs in two parts. The Eastern Pamirs, with their predominantly Kyrgyz population and high-altitude pastures around Murghab, Rangkul, Karakul, and Alichor, had been formally part of the Khanate of Kokand since 1776. After the dissolution of the Khanate in 1876, the Eastern Pamirs were incorporated into the Turkestan Governorate-General. Following the revolution, the Eastern Pamirs became part of the Ferghana Oblast' of the Turkestan Governorate-General's successor, the Turkestan Autonomous Soviet Socialist Republic (TASSR). The western part of the Pamirs had faced quite a different fate. After the 1895 Anglo-Russian border agreement, the districts of Rushan, Shughnan, Ishkashim, and Wakhan had been allocated to the Russian sphere of influence, and its administration was handed over to the Amir of Bukhara. This led to considerable grievances in the region, as the Amir regarded the predominantly Shia Ismai'li population as heretics. Alarming reports by two commanders of the Russian frontier detachment at the beginning of the twentieth century led to an official investigation of Bukharan misrule and finally to direct "temporary Russian administration," which allowed the local population a limited amount of self-rule. After the revolution, however, this temporary special status was abandoned and the Western Pamirs were integrated into the Bukharan People's Soviet Republic, the successor state of the Emirate of Bukhara (Bergne 2007, 33-34). In the context of the National-Territorial Delimitation, the Eastern and Western Pamirs were merged into the newly founded GornoBadakhshan Autonomous Region (Gorno-Badakhshanskaya avtonomnaya oblast', or GBAO) and incorporated into the Tajik Autonomous Soviet Socialist Republic, which was initially part of the Uzbek Soviet Socialist Republic and was subsequently promoted to the status of a Soviet Socialist Republic (SSR) in October 1929 (Bergne 2007, 1).

This brief summary of the admittedly much more complex cartographic process of National-Territorial Delimitation has to suffice here for the argument I seek to make: namely, that internal border delimitation in Soviet Asia corresponds to a kind of cartographic anxiety quite different from the one that infused Great Game politics. Rather than being concerned with 
spheres of influence, this new anxiety was concerned with the process of creating internal divisions suitable to the ideology of a voluntary union of mono-ethnic republics. Cartographic anxiety, here again, has to be read both as cartographic hope (for the envisioned fraternity of peoples, druzhba narodov) and cartographic fear (of pan-Muslim or pan-Turkic movements, for example). This exercise of mapping static natsional'nost' onto a region characterized by centuries of mobility and interethnic ties, however, necessarily remained incomplete. As we have seen, the Eastern Pamirs, with its predominantly Kyrgyz population, became part of the Tajik rather than the Kyrgyz SSR, despite the fact that neither Ismai'ili Pamiri nor Kyrgyz could identify with the new Tajik SSR. The creation of an autonomous region - the GBAO, comprising almost half of present-day Tajikistan's territory but only 3 percent of its population-continues to shape politics and lines of friction today.

The cartographic aspects of Soviet nationality policy-mapping natsional'nost' onto the borders of socialist republics and amending them where necessary with autonomous regionswas seen as crucial to gaining the long-term support of the non-Russian population of the Soviet Union. This was particularly true for border regions, where Soviet authorities were anxious to foster loyal and trustworthy borderland populations as a bulwark against hostile outside imperialism.

This endeavor concurred with a fascination with life in the borderlands. Soviet culture, Russian studies scholars Evgeny Dobrenko and Eric Naiman argue, "was a culture of inflamed borders. A border was the meeting space of two different topoi-the Soviet one and, without fail, an enemy one. The border lived its own special life, full of dangers and heroic feats, and therefore full of heroes and enemies" (Dobrenko and Naiman 2003, 186). Nation building, in this context, was a matter of extending the civilizational achievements of the center to the very peripheries. This sentiment found expression in songs, films, postal stamps, and publications like Pogranichnik (Border Guard), which covered the heroic lives of Soviet border troops (Shaw 2011; Günther 2003; Dobrenko and Naiman 2003). The geography of the diverse but united motherland became an important topic in schools, supported by patriotic books such as Nikolai Nikolaevich Mikhailov's (1947) Nad Kartoi Rodiny (On the map of the motherland), from which this article's epigraph is taken. It reads in full: "The red line blazed upon the world map-the border of the Soviet soil sparkled like the verge of two epochs, like a border between the past 
and the future. The line laid on the map, taking the stock of the fight: a new world has emerged on Earth — the world of socialism" (Mikhailov 1947, 4).

This concern with the outer boundaries of the Soviet Union as well as its internal division into republics according to ethnic criteria slowly but gradually shifted the scope and direction of relations in the borderlands. In the late 1920s, the Pamirs were still a crossroads of trade routes between Xinjiang and Central Asia. Traders exchanged tea, opium, dyes, wool, silk, and manufactured goods on a daily basis; a 1927 report complained that the southern border of the Tajik Autonomous Soviet Socialist Republic was “completely open” (Shaw 2011, 341); border troops were clearly struggling to control this situation.

Starting in 1929, forced collectivization and sedentarization curbed this mobility and severed long-standing cross-border relations. As elsewhere in the Soviet Union, these campaigns caused tremendous grievances. Peasants and herders felt betrayed and saw collectivization as nothing more than yet another attempt by an outside power to steal their property and freedom. A wave of out-migration from the Tajik Pamirs to China and Afghanistan was the result; among those taking refuge were even families of party members (Kreutzmann 2015, 277-281; Shaw 2011, 338-339, 343).

In the early 1930s, the Soviet state was still struggling to assert its sovereignty in the Pamirs. A report from Murghab complained that "party and state organs had been fully colonized by former state adversaries who committed a range of "blatantly anti-Soviet activities" (Shaw 2011, 343-344). Gradually, however, the party state got a firmer grip on the region and movement across the borders became more difficult. By the mid-1930s the borders were practically sealed; only occasionally would people dare to cross (Kreutzmann 2015, 114; Shaw 2011, 343) (figure 1).

While long-standing cross-border relations were grinding to a halt, relations within the Soviet Union became all the more important. This fundamental shift in orientation, role, and position - from a crossroads to a periphery — went hand in hand with infrastructural development and increasing material support for the Soviet Pamirs. Most importantly, a road was constructed through the Pamirs, linking Osh with Murghab and Khorog. The first vehicle arrived in Murghab in 1934 and regular traffic started a year later on what is now known as the Pamir Highway (Kreutzmann 2015, 114-115). At the same time, huge investments in civil infrastructure began to reconfigure Pamirian lives. On November 29, 1934, the Soviet newspaper Izvestia reported that 
Khorog is now lit with electricity that was started and first seen by the Pamir people in the spring of this year.... Aeroplanes are flying over inaccessible mountain ranges.... Formerly there was only one school in the whole of the Pamirs - now there are 140, and a training school for teachers: instead of dark smoky earth huts or skin tents, European houses are now being built: collective farms are established in the Pamirs, and they are growing and getting good crops of wheat, millet, and beans; and now they know how to manure their fields and be sure of good crop. (Quoted in Kreutzmann 2015, 278)

What we see is a double cartographic anxiety: Soviet authorities were not only anxious to secure the fragile border but also to make sure that socialism would not fade out toward the edge of the union. This double anxiety is captured well by Shaw's phrase "friendship under lock and key" (2011). To this end, extraordinary efforts were made to increase living standards in the Pamirs. According to Tobias Kraudzun, "more than 7,500 tons of goods had to be brought into the Pamirs in the planning year 1936/37 to supply about 29,000 people who were living in the region in $1935 "(2012,175)$.

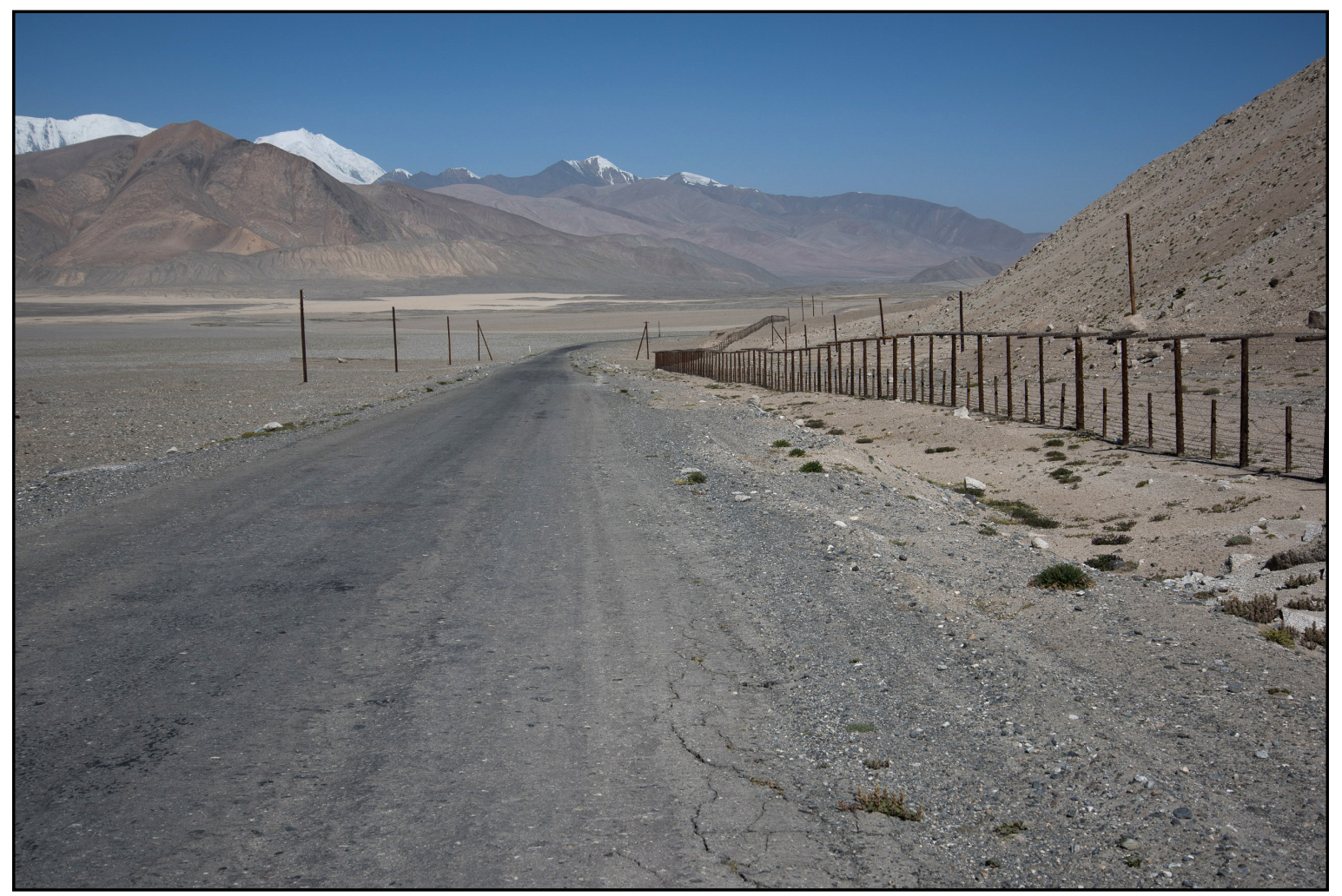

Figure 1. Soviet border fence along the Pamir Highway, 2015. Photo: Carolin Maertens. 
The logistics of this were too important to be left to the authorities of the Tajik and Kyrgyz Soviet Socialist Republics. A special organization, financed and controlled directly by Moscow, was set up: the Pamirskoe avtotransportnoe upravlenie (Pamir Transport Directorate, or PATU). PATU operated hundreds of trucks between Osh and Khorog (Kraudzun 2012, 177). Its lorry park (avtobaza) on the western outskirts of Murghab, anthropologist Till Mostowlansky notes, is remembered as a busy and happy place, where "state employed mechanics fixed cars... and their family members offered food and shelter to drivers" $(2013,66)$.

This form of direct "Moscow provisioning" (moskovskoe obespechenie) was not exclusive to the Pamirs or to any other border region. Other sites of strategic and ideological importance, such as mining towns, also enjoyed this special form of attention (Reeves 2014, 110-122). It meant not only that the state took full responsibility to cover the basic needs of the local population but also that those working in harsh and remote environments were given special salary bonuses (nadbavki). Above all, however, Moscow provisioning bestowed a particular role and position to a specific place on the map of the Soviet Union. As Reeves puts it, "It conveyed a certain kind of cultural and aesthetic connection — of the 'center in the periphery,' of Moscow multiplying outward and creating a direct and specific link to chosen settlements" (2014, 114).

Soviet development was without doubt enmeshed in what political scientist and anthropologist James Scott (1998) calls high modernism. Scott shows that, historically, highmodernist planning often implied a sweeping disregard for local conditions and local knowledge. The inherent "thin simplifications" of centrally planned high-modernist schemes, Scott argues, are often a recipe for disaster. Collectivization programs are one of the examples on which Scott builds his hypothesis of why so many high-modernist schemes to improve the human condition ultimately failed.

A high-modernist approach to planning can also be seen in the Pamirs. In the Wakhan Valley, for example, Soviet irrigation projects were started with the aim of turning the stony river banks of the Panj into hay meadows to help feed the cattle of the new collective farms. Eight-meter-deep irrigation channels were dug to harness the water of the main river, whereas traditional irrigation schemes relied exclusively on the rivers coming down the side valleys. The newly irrigated hay meadows were part of a larger attempt to scale up meat production as a replacement for traditional subsistence-oriented agro-pastoralism. The new irrigation channels, 
however, required constant maintenance, large machinery, and a continuous supply of diesel brought in from the city of Osh. Despite all of these measures, additional fodder had to be imported to feed the growing herds. Economically, this clearly modernist scheme never made sense, former Sovkhoz workers told me. What it did, however, was to provide the context in which smallholders could be turned into agricultural laborers, following the blueprint of agricultural planning throughout the Soviet Union.

Despite such cases, I contend that conceiving of the Soviet efforts in the Pamirs as highmodernist schemes without regard for local conditions does not do justice to the outcomes fostered on the ground. Marginality, as experienced during Soviet times, still carries positive connotations in the Pamirs (Mostowlansky 2013, 107). Remoteness defined a role and position that went along with a particular kind of connectivity to the center.

Rather than analyzing Soviet interventions through the lens of top-down modernist planning (and, perhaps, bottom-up local resistance), I suggest an approach I call "curational intervention." Here, curation has nothing to do with the work of museum curators. It is understood in a sense much closer to its original meaning of curare - to heal, or, more generally, to care for. Like high-modernist planning, curational intervention seeks to turn ideology (broadly understood) into palpable reality and experience. However, unlike high-modernist schemes, curational interventions tend to do so by means of a step-by-step approach rather than a sweeping gesture of radical change. Curation is more akin to constant gardening than strict oneoff implementation of a given technocratic design. Understood in this way, curation captures dimensions of the Soviet mode of engagement in the Pamirs that the notion of high-modernist schemes tends to forgo. Maintaining roads and running schools, hospitals, and a transportation directorate were not the sudden outcomes of central planning, but the result of continuous engagement with the Soviet Union's sensitive Pamirian borderlands. Despite the asymmetric relations of power involved (the curational impulse in the case at hand, after all, clearly originated in Moscow), this mode of engagement was to a certain extent collaborative, for an ongoing curational intervention can work only with at least partial consent.

Moscow provisioning was the symbol and hallmark of this continuing curational effort to turn the rugged mountains at the edge of the Soviet Union into a fertile socialist garden. While hardly sustainable, not without setbacks, and in hindsight often wasteful, the days of Moscow provisioning are clearly more than just another failed high-modernist scheme. In the Pamirs, they 
are remembered as an era of affluence, rather than one of disregard for local conditions. Diesel generators provided electricity in most settlements; regular and cheap flights from Murghab, Ishkoshim, and Khorog ensured ample connectivity; PATU trucks brought in a constant stream of goods; and petrol was so abundant that people used it to wash tires.

In summary, I argue that the shift from Great Game cartographic anxieties over spheres of influence to Soviet cartographic anxieties concerned with creating a home for a loyal borderland population went hand in hand with a changing mode of engagement - from a strategic and diplomatic one to a protective and curational one. Both left legacies behind and set the context in which present-day outside interventions are taking place.

\section{A Spectacle of Maps}

The unsettled border with China resurfaced as a cause for cartographic anxiety after the collapse of the Soviet Union and the end of the Cold War. When the Republic of Tajikistan and the People's Republic of China started negotiating the final settlement of their common borderline in the early 2000s (Alimov 2014), the Tajik government found itself faced with a Chinese claim to more than 20,000 square kilometers of territory in the Pamirs. This claim was based on the sections of the border left unmarked in the 1884 agreement and the Chinese standpoint that the subsequent exchange of notes in 1895, which established the de facto border during late imperial and Soviet times, was not legally binding. Finally, in 2004, an agreement was signed. The Chinese side dropped its far-reaching claims in exchange for a transfer of about 1,000 square kilometers of Tajik territory near Rangkul. Although the Tajik government advertised the outcome of these negotiations as a diplomatic success, the topic remained a sensitive issue, especially with regard to a similar agreement between Kyrgyzstan and China. Public opposition in Kyrgyzstan to this agreement was one of the factors that led to the ousting of the ruling Akayev family in 2005. The Tajik parliament was anxious about facing a similar backlash and therefore postponed ratification of the treaty year after year, only approving it in 2011.

The cartographic anxiety stemming from conflicting claims in this situation was countered by another type of cartographic anxiety, namely the ambition to reestablish the Tajik Pamirs as a trade route between western China and Central Asia, and beyond. The hopes and promises attached to this new Silk Road-an orderly version of its predecessor-were 
preconditioned on finally settling the dispute and establishing an official border crossing. The two anxieties - concerning territory and connectivity, respectively-were thus intrinsically linked to each other. Despite pending Tajik ratification, the 2004 agreement served as the basis to reopen the Kulma Pass that links Murghab (and the Pamir Highway) with Tashkurgan (and thus the Karakoram Highway). Today, around twenty logistics companies use the pass between Tashkurgan and Murghab to supply the bazaars of Tajikistan with Chinese goods.

In a certain way, the Kulma route, with its border infrastructure, lorry parks, and dry ports, is also an outcome of a curational intervention - one that seeks to translate the ideology of free but orderly trade into experience and reality. Unlike Moscow provisioning, however, the target of this intervention is only a corridor through the mountains and not the region itself. Symptomatically, most of the trucks from China just pass through, and the Chinese goods sold at the bazaars of Khorog or Murghab are usually not directly imported from China but purchased on the wholesale markets of Dushanbe, Osh, or Bishkek and shipped back to the Pamirs. Thus, people complain, the curated corridor does little to improve local livelihoods. The Pamirs are still as dependent on outside provisioning as during Soviet times. This became strikingly clear during the Tajik Civil War in the 1990s, when the region was cut off from the rest of Tajikistan and found itself on the verge of a famine. It was averted only by a decisive aid intervention organized by the Aga Khan Development Network. Today, the region is heavily dependent on remittances. Money earned in Russia pays for goods made in China - many of them transported twice through the Pamirs.

When Moscow provisioning came to an abrupt end with the collapse of the Soviet Union, it also left behind a much larger population relying on jobs no longer present and infrastructures no longer maintained. The ruins of this curational intervention are the context in which new anxieties and curational interventions now take place. The Soviet cartographic anxieties that underpinned Moscow provisioning and the special attention the region was given have been replaced by a spectrum of new cartographic ambitions and fears, of which the new Silk Road dream is only one. In fact, the past two decades have seen a veritable multiplication of cartographic anxieties. In this final section of the article, I examine two current examples of cartographic anxiety and ambition: the Tajik National Park and mining.

One of the anxieties that arose with the transition from a socialist planned economy to a capitalist market economy involved its potential environmental impact. Like the other anxieties 
described in this paper, the concern for environmental conservation originated outside the Pamirs - in the offices of international NGOs reasoning that the area's precarious economic situation would lead to increasing pressure on its mountain ecology (Breu, Maselli, and Hurni 2005). The developing energy crisis in the eastern Pamirs, triggered by a lack of funds to maintain the hydropower station in Murghab, and the high price of coal imported from the Kyrgyz Alai, led to increasing commercial harvesting of shrubs (teresken) in the Eastern Pamirs, widely seen as a threat to the fragile ecosystem (Kassam 2009; Breckle and Wucherer 2006). ${ }^{1}$ Also, NGOs expressed the fear that unregulated hunting, for both trophies and local meat consumption, would put increasing pressure on the wildlife population of ibexes, Marco Polo sheep, and snow leopards.

These ecological concerns have a distinctly cartographic dimension: conservation efforts typically involve the mapping of plant or wildlife populations and aim at creating bounded reserves where special rules apply. Such interventions also imply a clearly curational ambition: they are geared toward creating circumstances (institutions, rules, infrastructure) conducive to the realization of a particular ideology (biodiversity protection, participatory conservation, etc.). State-of-the-art methods adorned with three-letter acronyms-such as SDA (Sustainable Development Appraisal), the GLP (Global Land Project) framework, or a more systematic use of geographical information systems (GIS) — are typically advertised as means to help understand the local situation and design further interventions (Breu, Maselli, and Hurni 2005,140; Dear, Shigaeva, and Wolfgramm 2013).

One of the most interesting (yet incomplete) cases of a curational intervention emerging from ecological anxieties is the Tajik National Park, which was officially established in 1992, shortly after Tajikistan gained independence. Covering an area of almost 26,000 square kilometers, it is the biggest protected area in Central Asia. The park has attracted the keen interest of environmental NGOs - not so much in its current form but as a potential avenue toward a particular vision of the future. In a 2003 summary report on protected areas and world heritage, Jim Thorsell (2003) wrote: "The TNP [Tajik National Park] and even its Kyrgyz neighborhood could... serve as an interesting transboundary 'exercise field' for using and further developing participatory methodologies and tools to promote SRM [sustainable resource management]" (Thorsell 2003, 297). 
Despite the attachment of such hopes to the park's existence on official maps, it has also been a source of headache and continual frustration for environmental NGOs (Haslinger et al. 2007; Graaff 2015). Geographer Andrea Haslinger and her colleagues from the CDE, for example, complained that the Park Authority consisted only of some officials based in Dushanbe with vested interest but poor knowledge, while the local population was largely ignorant about the park's very existence, not to mention its boundaries and rules. Quoting a member of the Nature Protection Committee in Murghab who said that the park "officially exists only in Dushanbe, but not here," the authors concluded that a number of measures were urgently needed for the park to live up to its promise, including a redefinition of the borders and usage zones and a better stakeholder process that ensures local awareness as well as opportunities for sustainable usage of its resources (Haslinger et al. 2007, 160, 167).

Nevertheless, between 2005 and 2008 the State Department of Natural Protected Areas of Tajikistan together with the Natural Heritage Protection Fund, a Moscow-based organization dedicated to the support of World Heritage sites in the former Soviet Union, drafted an application for inclusion of the park in the UNESCO World Heritage list (Natural Heritage Protection Fund 2009, 2013b). To gain approval, it evoked a vision of empty space (not unlike the one conjured up by Great Game explorers): "Natural objects and landscapes of the park till now are not touched by man and serve as source [sic] of exceptional aesthetic pleasure and charged [sic] by inexpressible natural power" (Natural Heritage Protection Fund 2013a). Despite concerns on the part of the International Union for Conservation of Nature (IUCN 2014), the application went through; in June 2013 the Tajik National Park officially became a UNESCO World Heritage Site. Remarkably, and in spite of the distinctly cartographic nature of establishing a nature reserve by delimiting a space for conservation, the official UNESCO documentation lacks a precise map of the park's boundaries. And, surely, the boundaries have by and large remained unmarked on the ground. Robert Middleton, author of Tajikistan and the High Pamirs (2011), wrote a letter of concern to UNESCO:

I was delighted to learn of the designation of the Pamirs as a UNESCO World Heritage Site. I regret, however, that this designation is defined by the appellation "Tajikistan National Park", that bears no relationship to facts on the ground. The "Park" has no clearly defined (much less publicly designated) boundaries, no ranger personnel and no funding. Apart from those like myself who are only concerned to promote ecotourism in the Pamirs, those most interested in this new 
honour will certainly be the Tajik government - which has an excuse to levy fees from tourists for non-existent park services and non-planned investments in the protection of the site. ${ }^{2}$

Note that the park, officially sanctioned yet strangely unmarked, continues to be a site where cartographic anxiety and curational ambitions form the backdrop to a variety of vested interests and visions of the future. While the park, despite being graced by UNESCO World Heritage approval, may not be very effective in terms of conservation, its proclamation nevertheless established a mode of engagement that sanctions certain activities, including ecotourism and even legal trophy hunting, while it bans others (Weaver 2013). UNESCO documents on the Tajik National Park state that "the legislative framework and management arrangements for the property are comprehensive and clear and all activities that could threaten the integrity of the property, including mining, are legally prohibited" (UNESCO 2013). This is in direct contradiction to another form of current cartographic ambition in the region: mining.

The idea of the Pamirs as the El Dorado of precious minerals has long inspired outside interest. The Spinel (Ruby) mines of Kuh-i Lal and Kurkut (the former dating back to the ninth century) and the ruins of the silver mining town of Bazar Dara (founded in the eleventh century) are testimony to the long history of mineral extraction in the area. There are more than two hundred mineral deposits of interest in the Pamirs, which Soviet geological expeditions actively started mapping in the 1950s. ${ }^{3}$ However, due to the rugged terrain and the lack of suitable infrastructure, the Soviet mining industry by and large ended up focusing on regions closer to existing railway lines, such as at the southern rim of the Fergana Valley. In the Pamirs, the Soviet quest for mineral wealth remained largely exploratory.

Since Tajikistan's independence, these Soviet geological maps have attracted renewed attention. Several companies acquired mining rights to large areas in the Pamirs and continued prospecting on the basis of these existing documents. Since the 1990s, mining rights have frequently changed hands and, as is often the case in the mining sector, complex holding structures and subcontracting agreements render the situation rather opaque. In the case of Bazar Dara, the rights changed hands five times between 1995 and 2007. In 2007, a subsidiary of the Kazakh copper mining company Kazakhmys acquired the rights to and continued exploration along a shaft that a Soviet expedition had started in the late 1970s. In 2015, a Chinese-led 
conglomerate took over from Kazakhmys. At the time of my last visit, in June 2015, about sixty people were working in the mine, most of them Chinese.

The anxieties and hopes related to mining are directly tied to maps. Detailed cartographic knowledge of deposits is a major asset, not just for actual extraction but also for the value of a mining concession. Detailed maps are thus usually not publicly accessible, and official documentation provides only summary listings of companies, areas, and deposits. Notably, however, the Bazar Dara mining area lies within the territory of the Tajik National Park. In this case, two cartographic anxieties - the anxiety to protect the fragile mountain ecology and the anxiety to develop the mining sector in the structurally poor GBAO_relate to the same territory. Given the fuzzy and still unmarked boundaries of the park and the as-of-yet small-scale exploratory nature of mining, this overlap has so far not attracted official or public attention.

Mining, the Tajik National Park, and the transport corridor from Kashgar across the Kulma Pass to Dushanbe are just three examples of the wide palette of contemporary cartographic anxieties and ambitions the Pamirs have faced since independence. This multiplicity of cartographic anxieties and hopes is characteristic of the current situation. With their diverse ideological underpinnings and visions of the future, these anxieties are directly linked to rather different and sometimes conflicting modes of engagement.

\section{Conclusions}

The concept of cartographic anxiety may not tell us much about the outcomes of the projects that arise from it, or about the friction, resistance, and appropriation such projects encounter. I hope I have shown, however, that the notion of cartographic anxiety can provide a lens onto certain kinds of concerns that typically originate in centers of power far away from the targeted areas. Embedded in particular ideologies, cartographic anxieties thereby inform particular modes of engagement. These modes of engagement-strategic, diplomatic, curational, exploratory, or extractive - are typically fraught with strong asymmetries of power.

Cartographic anxieties - as both fears and ambitions deriving from and producing maps - cover a variety of scales: from the spheres of influence during the Great Game to the endeavor of mapping ethnic boundaries onto multiethnic places; from the quest to delimit the boundaries of a nature reserve or establish a transportation corridor to the spatial designation of a mining concession. The maps used and produced in these contexts are not just concerned with 
representing existing geographic realities; first and foremost, they are concerned with anticipated outcomes and visions of particular futures. This future-oriented, ontogenetic character often builds on an imaginary of empty space ready to be filled and shaped in service of a particular goal.

While cartographic anxieties emerge from maps and lead to the production of maps, mapping is only one - often not the first and hardly ever the last—step in the ontogenetic processes they set in motion. Cartographic anxiety is usually triggered by an idea, an event, or sometimes just a rumor-in short, by something that calls for action. At first, a line might be drawn on a map, but then a fence, a border post, or a road is built. In the course of such spatial interventions, the idea of empty and easily moldable space necessarily evaporates as an intervention take shape in the context of an already existing environment. However, the task to make a border work (Reeves 2014) seldom takes place just along the borderline itself. More often, it plays out along routes or in specific nodes of control (Farrelly 2013) in relation to a border. At this point, things become social, messy, and a matter of everyday practice.

In the course of this process, the map that claims, entitles, or bans may almost disappear behind the social realities in which the intervention becomes engulfed. ${ }^{4}$ Nevertheless, the anxieties and ambitions attached to it may not lose any of their power. Activities that are legal and licit inside one spatially designated area become risky in another. Interventions meant to mitigate cartographic anxiety (or fulfill its promise) by means of more and better mapping often end up creating new cartographic anxieties. This is especially true when a multiplicity of cartographic anxieties is at work, as is the case in the Pamirs today. Scrutinizing this spectacle of ontogenetic maps may help us contextualize and better understand the forces at stake in the Pamirs and elsewhere.

Martin Saxer is an anthropologist at the Department of Social and Cultural Anthropology, Ludwig Maximilian University of Munch. He is the principle investigator of the research project "Remoteness \& Connectivity: Highland Asia in the World" funded by the European Research Council. Research for this article was conducted with the generous support of the European Research Council (Starting Grant 637764, Highland Connections). The author would like to thank Caroline Maertens, Alessandro Rippa, Till Mostowlansky, Franck Bille, and the anonymous reviewers for their insightful comments on various versions of this article. 


\section{Notes}

${ }^{1}$ Recent findings (Kraudzun, Vanselow, and Samimi 2014), however, sound less alarming.

${ }^{2}$ See the Pamirs Travel website at http://www.pamirs.org/travel.htm.

${ }^{3}$ According to an investment brochure handed out at the First International Economic Forum held in Khorog in August 2013, however, only twelve of these deposits have ever been actively mined.

${ }^{4}$ Consider, for example, how hard it is to find accurate maps of mining concessions or even the territory in the Rangkul area handed over to China in 2011.

\section{References}

Abashin, Sergei. 2014. "The 'Fierce Fight' at Oshoba: A Microhistory of the Conquest of the Khoqand Khanate." Central Asian Survey 33 (2): 215-231.

Alimov, Rashid. 2014. "Strategicheskoe partnerstvo Tadzhikistana (RT) i Kitaya (KNR): Mezhdunarodno-politicheskiye, ekonomicheskie i gumanitarnie izmereniya" [Strategic partnership of Tajikistan and China: Transborder political, economic, and humanitarian dimensions]. Ph.D. diss., Diplomatic Academy of the Foreign Ministry of the Russian Federation.

Baudrillard, Jean. 2002. Selected Writings. Edited by Mark Poster. Stanford, CA: Stanford University Press.

Bazarbayev, Kanat, and Zabirash Ashimkhanovna Adilbekova. 2012. "Jadids Movement in Central Asia in the Late 19th and the Early 20th Centuries." Asian Social Science 8 (8): 225-237.

Bergne, Paul. 2007. The Birth of Tajikistan. National Identity and the Origins of the Republic. London: I. B. Tauris.

Breckle, Siegmar W., and Walter Wucherer. 2006. "Vegetation of the Pamir (Tajikistan): Land Use and Desertification Problems." In Land Use Change and Mountain Biodiversity, edited by Eva M. Spehn, Christian Körner, and Maximo Liberman, 225-237. Boca Raton, FL: CRC Press.

Breu, Thomas, Daniel Maselli, and Hans Hurni. 2005. "Knowledge for Sustainable Development in the Tajik Pamir Mountains." Mountain Research and Development 25 (2): 139-146.

Campbell, Ian W. 2014. "'Our Friendly Rivals': Rethinking the Great Game in Ya'qub Beg's Kashgaria, 1867-77.” Central Asian Survey 33 (2): 199-214.

Curzon, George Nathaniel. 1907. Frontiers. Oxford: Clarendon Press.

Dear, Chad, Jyldyz Shigaeva, and Bettina Wolfgramm. 2013. "Assessing the State of Sustainable Land Management Research in Kyrgyzstan and Tajikistan.” Mountain Research and Development 33 (4): 443-452.

de Certeau, Michel. 1984. The Practice of Everyday Life. Berkeley: University of California Press.

Dobrenko, Evgeny, and Eric Naiman. 2003. The Landscape of Stalinism: The Art and Ideology of Soviet Space. Seattle: University of Washington Press.

Ewans, Martin. 2010. Securing the Indian Frontier in Central Asia: Confrontation and Negotiation, 1865-1895. Milton Park, UK: Routledge. 
Farrelly, Nicholas. 2013. "Nodes of Control in a South(east) Asian Borderland." In Borderland Lives in Northern South Asia, edited by David Gellner, 194-213. Durham, NC: Duke University Press.

Fraser, Glenda. 1987. "Basmachi-I." Central Asian Survey 6 (1): 1-73.

Garver, John W. 1981. "The Sino-Soviet Territorial Dispute in the Pamir Mountains Region." The China Quarterly 85: 107-118.

Geographer Office of the Geographer Bureau of Intelligence and Research. 1983. "AfghanistanU.S.S.R. Boundary.” Available at http://www.juldu.com/Pamir/Wakhan.pdf, accessed February 12, 2016.

Gordon, Thomas Edward. 1875. "Sirikol, the Pámírs and Wakhán.” In Report of a Mission to Yarkund in 1873, edited by Douglas Forsyth, 222-232. Calcutta: Foreign Department Press.

Graaff, Nico. 2015. "Needs Assessment and Opportunity Study of the Tajik National Park Focusing on Its Potential as a Tourism Destination." Khorog: Pamir Eco-Cultural Tourism Association (PECTA).

Grieshuber, Josef, and Sergei Churkin. 2003. "Grum-Grshimailo's Journey through China with Notes on Some Colias Taxa." Helios 4: 224-243.

Günther, Hans. 2003. "Broad Is My Motherland": The Mother Archetype and Space in the Soviet Mass Song." In The Landscape of Stalinism, edited by Evgeny Dobrenko and Eric Naiman, 77-95. Seattle: University of Washington Press.

Habberton, William. 1937. Anglo-Russian Relations Concerning Afghanistan, 1837-1907. Urbana: University of Illinois Press.

Haslinger, Andrea, Thomas Breu, Hans Hurni, and Daniel Maselli. 2007. “Opportunities and Risks in Reconciling Conservation and Development in a Post-Soviet Setting: The Example of the Tajik National Park." International Journal of Biodiversity Science, Ecosystems Services and Management 3: 157-169.

Haugen, Arne. 2003. The Establishment of National Republics in Central Asia. Basingstoke, UK: Palgrave Macmillan.

Hedin, Sven. 1898. Through Asia. Vol. 1. London: Methuen and Co.

Hirsch, Francine. 2005. Empire of Nations: Ethnographic Knowledge and the Making of the Soviet Union. Ithaca, NY: Cornell University Press.

Hopkins, Benjamin D. 2008. The Making of Modern Afghanistan. Basingstoke, UK: Palgrave Macmillan.

Hopkirk, Peter. 1990. The Great Game: On Secret Service in High Asia. London: Murray.

IUCN. 2014. "Tajik National Park (Mountains of the Pamirs)." World Heritage Outlook. May 26. Available at http://www.worldheritageoutlook.iucn.org/search-sites/-/wdpaid/en 1555556049, accessed December 26, 2016.

Kassam, Karim Aly. 2009. "Viewing Change through the Prism of Indigenous Human Ecology: Findings from the Afghan and Tajik Pamirs." Human Ecology 37 (6): 677-690.

Keay, John. 1977. When Men and Mountains Meet: The Explorers of the Western Himalayas, 1820-1875. London: Murray.

Kitchin, Rob, and Martin Dodge. 2007. "Rethinking Maps.” Progress in Human Geography 31 (3): 331-344.

Kraudzun, Tobias. 2012. "From the Pamir Frontier to International Borders: Exchange Relations of the Borderland Population." In Subverting Borders: Doing Research on Smuggling 
and Small-Scale Trade, edited by Bettina Bruns and Judith Miggelbrink, 166-186. Wiesbaden: VS Verlag.

Kraudzun, Tobias, Kim André Vanselow, and Cyrus Samimi. 2014. "Realities and Myths of the Teresken Syndrome: An Evaluation of the Exploitation of Dwarf Shrub Resources in the Eastern Pamirs of Tajikistan.” Journal of Environmental Management 132: 49-59.

Kreutzmann, Hermann. 2015. Pamirian Crossroads: Khirgiz and Wakhi of High Asia. Wiesbaden: Harrassowitz Verlag.

- 2016. "Pamirian Spaces: Mapping Process Geographies in the Mountainous Periphery." In Mapping Transition in the Pamirs, edited by H. Kreutzmann and T. Watanabe, 1-16. Cham, Switzerland: Springer.

Lattimore, Owen. 1950. Pivot of Asia: Sinkiang and the Inner Asian Frontiers of China and Russia. Boston: Little, Brown and Company.

Ludden, David. 2003. "Presidential Address: Maps in the Mind and the Mobility of Asia." The Journal of Asian Studies 62 (4): 1057-1078.

Martin, Terry. 2001. The Affirmative Action Empire. Nations and Nationalism in the Soviet Union, 1923-1939. Ithaca, NY: Cornell University Press.

Middleton, Robert. 2011. Tajikistan and the High Pamirs: A Companion and Guide. 2nd ed. Hong Kong: Odyssey.

Mikhailov, Nikolai Nikolaevich. 1947. Nad kartoi rodiny [On the map of the motherland]. Moscow: Molodaia Gvardiia.

Morrison, Alexander. 2013. "Review of 'Bol'shaia igra, 1856-1907: Mify i realii rossiiskobritanskikh otnoshenii v Tsentral'noi i Vostochnoi Azii.' By E. Sergeev. Moscow: Tovarishchestvo nauchnykh izdanii KMK, 2012." Slavic Review 72 (4): 892-893.

Mostowlansky, Till. 2013. "Azan on the Moon: Entangling Modernities along Tajikistan's Pamir Highway." PhD diss., University of Bern.

- 2014. "Introduction: Killing the Cotton Canard and Getting Rid of the Great Game:

Rewriting the Russian Conquest of Central Asia, 1814-1895." Central Asian Survey 33 (2): 131-142.

Natural Heritage Protection Fund. 2009. "IUCN Expert Mission to the Tajik National Park." Available at http://www.nhpfund.org/news/2009-10-07.html, accessed February 5, 2016. . 2013a. "Tajik National Park.” Available at http://www.nhpfund.org/sng/tajik-np.html, accessed February 5, 2016. . 2013b. "Tajik National Park (Pamir Mountains) Has Been Inscribed on the List by the World Heritage Committee.” Available at http://www.nhpfund.org/news/2013-0621.html, accessed February 5, 2016.

Olcott, Martha B. 1981. "The Basmachi or Freemen's Revolt in Turkestan, 1918-24." Soviet Studies 33 (3): 352-369.

Rawlinson, H. C. 1872. "Monograph of the Oxus." The Journal of the Royal Geographical Society of London 42: 483-513.

Reeves, Madeleine. 2014. Border Work: Spatial Lives of the State in Rural Central Asia. Ithaca, NY: Cornell University Press.

Ritter, William S. 1985. "The Final Phase in the Liquidation of Anti-Soviet Resistance in Tadzhikistan: Ibrahim Bek and the Basmachi, 1924-31." Soviet Studies 37 (4): 484-493.

Rowe, William Campbell. 2010. "The Wakhan Corridor: Endgame of the Great Game." In Borderlines and Borderlands: Political Oddities at the Edge of the Nation-State, edited by Alexander C. Diener and Joshua Hagen, 53-68. Plymouth: Rowman and Littlefield. 
Sabol, Steven. 1995. "The Creation of Soviet Central Asia: The 1924 National Delimitation." Central Asian Survey 14 (2): 225-241.

Scott, James C. 1998. Seeing Like a State: How Certain Schemes to Improve the Human Condition Have Failed. New Haven, CT: Yale University Press.

Sergeev, Evgeny. 2013. The Great Game, 1856-1907: Russo-British Relations in Central and East Asia. Baltimore, MD: Woodrow Wilson Center and Johns Hopkins University Press.

Shaw, Charles. 2011. "Friendship under Lock and Key: The Soviet Central Asian Border, 191834." Central Asian Survey 30 (3-4): 331-348.

Shaw, Robert. 1871. Visits to High Tartary, Yarkand, and Kashghar (Formerly Chinese Tartary), and Return Journey over the Karakorum Pass. London: John Murray.

Thongchai, Winichakul. 1994. Siam Mapped: A History of the Geo-Body of a Nation. Honolulu: Hawai'i University Press.

Thorsell, Jim. 2003. "A Global Overview of Mountain Protected Areas on the World Heritage List." Mountain Research and Development 23 (3): 290-291.

UNESCO. 2013. "Tajik National Park (Mountains of the Pamirs): UNESCO World Heritage Centre." Available at http://whc.unesco.org/pg.cfm?cid=31\&id_site=1252, accessed February 5, 2016.

Weaver, Chris L. 2013. "The Potential for Sustainable Hunting Management in the Context of the Tajik National Park and the Recently Established Tajik World Heritage Site." Feasibility Study. Deutsche Gesellschaft für Internationale Zusammenarbeit (GIZ).

Weller, Charles R. 2014. "The Great Game, 1856-1907: Russo-British Relations in Central and East Asia, by Evgeny Sergeev, John Hopkins University Press, 2013 (Review).” Reviews in History. Available at http://www.history.ac.uk/reviews/review/1611, accessed July 25, 2016.

Younghusband, Francis Edward. 1896. Heart of a Continent: A Narrative of Travels in Manchuria, across the Gobi Desert, through the Himalayas, the Pamirs, and Chitral, 1884-1894. London: John Murray. 